\title{
Hunger and the Issue of Agricultural Productivity in Congo
}

\author{
Mayéko Léon \\ Ph.D, Senior Lecturer, Marien NGOUABI University, PoBox 69, Brazzaville Congo. \\ Email: ngodoleon@yahoo.fr or mayeko.leon@gmail.com
}

\author{
Received: June 24, $2019 \quad$ Accepted: Dec. 17, $2019 \quad$ Published: Jan. 3, 2020 \\ doi:10.5296/jas.v8i2.16177～URL: https://doi.org/10.5296/jas.v8i2.16177
}

\begin{abstract}
In the Congo agricultural techniques of agricultural households base agricultural productivity on the physical aptitudes of the members of these households. In rural areas, however, the hunger affects a large majority of households, especially households headed by households in an agricultural industry. Improving agricultural productivity in this situation is a crucial issue as household members no longer consume the required calories.

Ordinary least squares regression has yielded results that indicate that an increase in the number of undernourished people has a negative impact on agricultural productivity.
\end{abstract}

Keywords: hunger, agricultural productivity, farming households, cassava root, undernourishment

\section{Introduction}

At the opening Conference of the United Nations for Food and Agriculture Organization (FAO) in Rome in June 2013, the 1998 Nobel Prize Laureate Sen A. said: "If the world wants to fight hunger, it must address all its causes simultaneously, especially poverty, and not just focus on increasing food production."

Hunger, the eradication of which is one of the targets of the Sustainable Development Goals (SDGs), was already central in the 1950s, when Josué de Castro' ${ }^{1}$ s ideas helped to understand its causes and attract attention of the international community on the issues of hunger. One of

\footnotetext{
${ }^{1}$ These works on hunger makes him elect in 1951 president of the council of the United Nations Food and Agriculture Organization (FAO)
} 
Josué de Castro's contributions is that hunger, far from being a natural phenomenon, is a social scourge, mainly caused by unfair economic structures.

Hunger and famine, which for $\operatorname{Sen}^{2}$ is caused by the fact that some people do not have access to enough food, have resurfaced the notion of scarcity. It is therefore to fight against hunger and famine which is nothing but a rarity. A hungry person has the oxygen of the air that is essential for his survival. However the air remains of no economic value since it is accessible to all and is in unlimited quantity. Access to enough food for a hungry person allows him to satisfy a specific need: hunger. The satisfaction of this specific need is a utility for this hungry person.

A hungry person who has nothing or not enough to trade, whether it is his job, money on the land or any other right he can bargain on the market or turn into value for food (Sen, 1981) ${ }^{3}$.

FAO generally uses the prevalence of undernourishment as an indicator to monitor hunger at the regional and global levels. Hunger and famine are a concern in Africa, particularly in sub-Saharan Africa, where an estimated ${ }^{4} 23.2 \%$ of the population is between one in four and one in five in the region suffers from chronic food deprivation in 2017. The number of undernourished people in sub-Saharan Africa, according to the same sources, increased from 181 million in 2010 to nearly 222 million in 2016, an increase of $22.6 \%$ in six years. In 2017 this figure was more than 236 million $^{5}$.

Joshua de Castro admits that "one of the major obstacles to finding adequate solutions to the problem of people's food lies precisely in the lack of knowledge of the problem as a whole, that is to say, like a complex of simultaneously biological, economic and social manifestations"

According to FAO et al. (2018), to be free from hunger and all forms of malnutrition by 2030, it is imperative to accelerate and intensify actions to strengthen the resilience and adaptive capacity of food systems, as well as people's means of existence face to the climate variability and extreme weather events.

Sen $A^{7}$ pointed out that "for Africa, which does not have a steady increase in per capita food availability ... it is therefore appropriate to give priority to initiatives that increase food production more vigorously than 'before'. He further emphasized that "for Africa's long-term economic stability and security, economic diversification is crucial."

\footnotetext{
${ }^{2}$ See Sen's presentation to the FAO conference in Rome in June 2013.

${ }^{3}$ Cité par Assidon E. (2002), op.cité.

${ }^{4}$ FAO, IFAD, WHO, WFP and UNICEF. (2018), The State of Food Security and Nutrition in the World. Strengthen resilience to climate change for food security and nutrition. Rome, FAO.
}

${ }^{5}$ See FAO, IFAD, WHO, WFP and UNICEF. 2018.

${ }^{6}$ Joshua de Castro (2003), Geography of Hunger, Rio de Janeiro. Brazil.

${ }^{7}$ See FAO Conference, Rome 15 June 2013. 
From 2010 to 2014 , the high level of oil prices on the international market ${ }^{8}$ has allowed the government of Congo to reap substantial oil surpluses which as a measure of fiscal prudence, were placed in a "stabilization account" at the Central Bank and have been added to state bank deposits in China. The Congo was therefore in a favorable position to stimulate a stronger growth momentum and an acceleration of public investment spending, thus enabling the population of poor $^{9}$ households to receive essential medical care, basic food and education necessary.

The essential conditions were thus met to enable the Congo to eradicate hunger, if not to improve the level of hunger. However, when we look at the evolution of the Global Hunger Index (GHI), or hunger index ${ }^{10}$ of the International Food Policy Research Institute (IFPRI), we can see that the state of hunger in Congo remains worrying. While the level of hunger in the Congo has decreased at an average annual rate of 55.6\% between 2010 and 2012, from 15.2 to 11.4 (a situation of moderate hunger), the situation has radically reversed between 2012 and 2014 with levels of hunger that rose respectively from $79.8 \%$ and $28.3 \%$ from 2012 to 2013 and from 2013 to 2014 around 26.3 a score that reflects a serious situation ${ }^{11}$.

It is recognized that Congolese farm households still have difficulty adapting to new farming techniques that would allow them to adopt an appropriate approach to manage soils, water, plants and animals as components of a functional unit as advocated by FAO (1992) ${ }^{12}$. As these farming households still practice an agriculture dependent on the period and the quality of the rains, they are thus exposed to climatic hazards and can easily switch to extreme poverty, especially hunger.

Farming techniques of agricultural household's base agricultural productivity on the physical abilities of individuals in these households. However, monetary poverty affected $74.8 \%$ of rural areas according to the last Congolese household survey (ECOM2) in 2011. This rate is increasing compared to ECOM1 (64.8\%). For households where the head of household operates in an agricultural industry, this rate rose from 47.8\% (ECOM1) to 64.3\% (ECOM2) in 2005.

It is recognized that producing more using the same amounts of labor and capital is an increase in productivity. Thus, productivity measures the efficiency of the production process.

\footnotetext{
${ }^{8}$ The international price of the barrel was $79 ; 104 ; 105 ; 104$; US \$ 96.26 and US \$ 50.8 from 2010 to 2015.

${ }^{9}$ The proportion of the Congolese population living below the monetary poverty line, or 544.40 F.CFA per adult per day, increased from 50.7\% in 2005 to $46.5 \%$ in 2011 according to the Congolese Survey of Households (ECOM 1 and 2).

${ }^{10}$ See ACTED et al. World Hunger Index, 2010, 2011, 2012, 2013, 2014, 2015, 2016 and 2017.

${ }^{11}$ According to the International Food Policy Research Institute (IFPRI), the severity scale of the GHI is: less than or equal to 9.9 low; from 10 to 19.9 moderate; from 20 to 34.9 serious; from 35 to 49.9 alarming and finally 50 extremely alarming.

${ }^{12}$ See Pierre Antonios (2002) "Sustainable agricultural development: dream or reality?" Courier ACP-EU, No. 139, July-August.
} 
For a poor farm household where a large number of workers work in agriculture and where food absorbs the bulk of production, improving agricultural productivity becomes a crucial issue, as household members no longer consume the necessary calories required.

It is accepted that the severity of hunger is related to the extent of poverty. Also, hunger can lock agricultural households into a vicious cycle of low agricultural productivity. But paradoxically, it is noted that the agricultural households, producers of agricultural products that have a food situation or nutritional worrying.

With the collapse of oil prices, Congo finds itself in a less favorable position: a serious deterioration of public finances that requires budgetary adjustments, thus preventing a greater capacity of the State to spend in the social sectors, especially those related to the SDGs. This collapse of oil barrel prices combined with post-election armed conflict in the Pool Department has certainly deteriorated the poverty line. This deterioration would be widespread in the Pool, especially at the level of agricultural households. Indeed, if in 2011 the poverty line of these households had reached $59.6 \%$, that is to say $71.8 \%$ of the population, it would be today at a higher level than that of 2011. We can also observe this situation in Pointe-Noire with unemployment affecting the petroleum sector of activities (subcontracting) and in households headed by a retired person and an agent of the Congo-Ocean Railway (CFCO) who respectively accumulate arrears of pensions and wages.

Hunger through the indicator undernourishment prevalence shows that the number of undernourished people, on average three years, rose from 1.8 million between 2010 and 2012 to 1.9 million between 2015 and $2017^{13}$. Similarly, since 2013, the hunger index has been on a serious gravity scale, rising from $20.5 \%$ in 2013 to $25.6 \%$ in $2017^{14}$.

Thus, our study attempts to analyze the impact that hunger may have on the productivity of an undernourished individual in an agricultural household. So the question that underlies our work is whether hunger deteriorates the productivity of poor farm households in Congo?

This study is structured in three essential points namely: the figures on the evolution of the hunger (I), the literature on the hunger and the agricultural yield (II) and finally the econometric analysis (III).

\section{Figures on the Evolution of Hunger in Congo}

At the World Food Conference in 1974, Heads of State and Government set themselves the goal of eradicating hunger, food insecurity and malnutrition by in ten year-time. However, more than 10 years later, in 2015 the issue of hunger was again put on the agenda with the Sustainable Development Goals (SDGs). The SDGs aimed at "eliminating hunger, ensuring food security, improving nutrition and promoting sustainable agriculture".

\footnotetext{
${ }^{13}$ See FAOSTAT 2019.

${ }^{14}$ See ACTED op. city.
} 


\section{Macrothink}

Sen (1981) showed that famine outbreaks were not necessarily a direct result of a lack of food following a poor harvest, but were more dependent on political conditions and speculation.

By emphasizing that hunger is a social scourge, caused mainly by unfair economic structures, de Castro made it clear that this scourge does not only depend on harvests, but also on the market. When the market is poorly supplied (the question of supply and demand) there is a rise in prices. There is a supply of food but there is no money to buy it, because the market does not allow to maintain prices that allow all to feed. An opposite situation may also arise where the level of market prices does not allow agricultural households to cover production costs and thus keep them in a situation of impoverishment.

Isn't the gravity of hunger the manifestation of a real difference observed in developing countries between the official discourse and the different actions carried out? The reduction of the hunger index thus passes through the real ends pursued by the political authorities.

Thus, hunger would still be a worrying problem and could even worsen in some countries and turn into riots, where some developing countries in general and in particular Sub-Saharan African countries are doing just thanks to 'help.

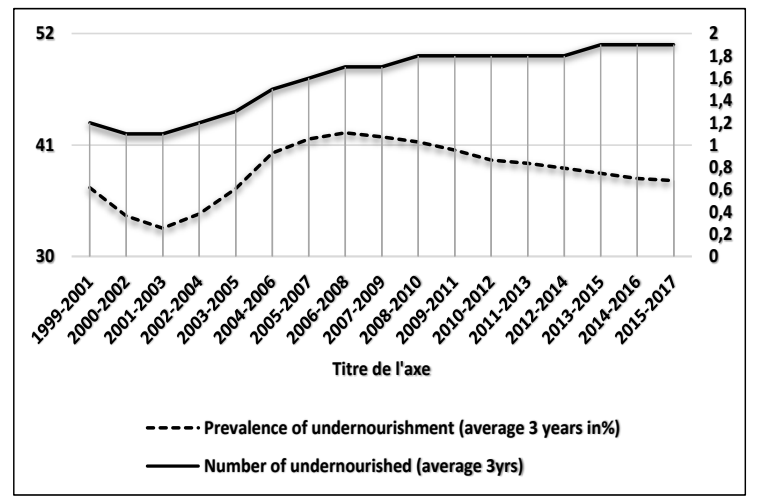

Graph 1. Prevalence of undernourishment and number of undernourished people

FAO_STAT 2019

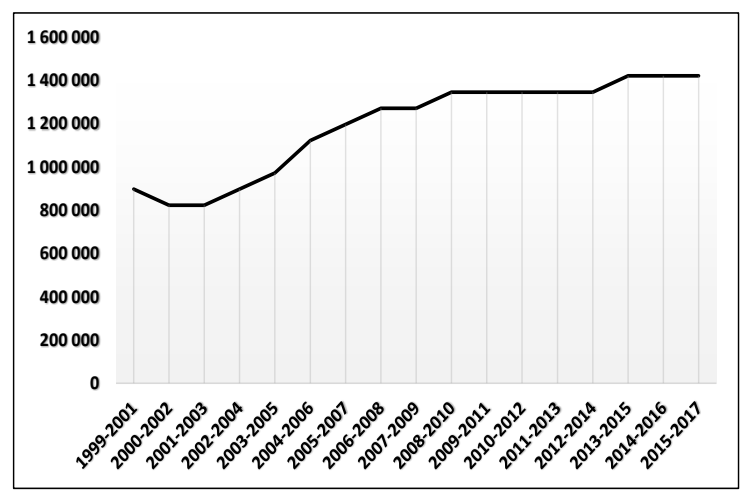

Graph 2. Number of malnourished rural poor (average 3 years)

FAO_STAT 2019 


\section{Macrothink}

The observation of Charts 1 and 2 indicates that the trend in the number of undernourished and the number of malnourished poor in rural areas is steadily increasing. The average number of undernourished rural poor between 2015 and 2017 is far from the level of the 1999-2000 period. This number rose from 897600 to 1.4 million, a difference of 52,300 poor undernourished. Although the curve of the prevalence rate of undernourishment marks a downward trend, this rate is far from returning to the low level of the 2001-2002 period.

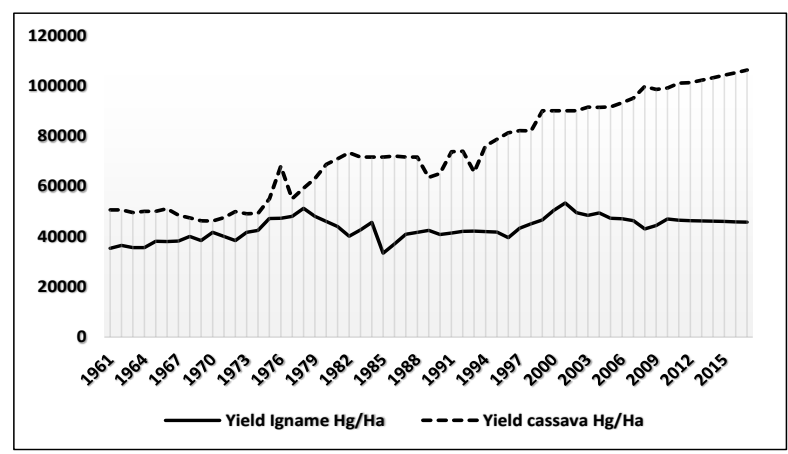

Graph 1. Yield of cassava and yam production in hg / ha

FAO_STAT 2019

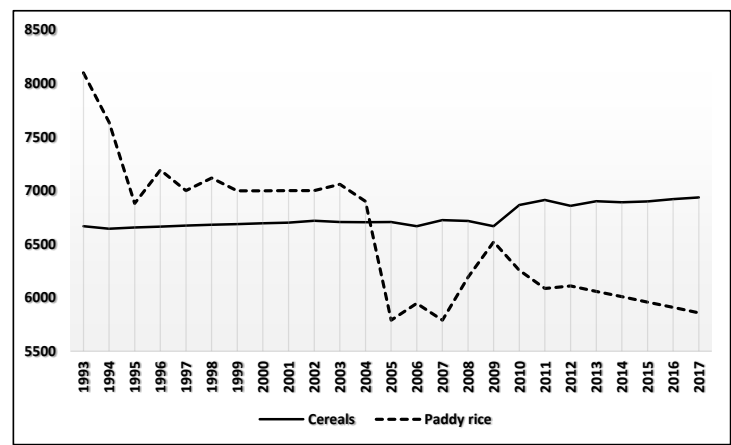

Graph 2. Yield of cereals and paddy rice in hg / ha

FAO_STAT 2019

For temporary crops ${ }^{15}$, tubers certainly occupy the first rank with 236822 households or farms for an active labor force of 462811 individuals. 47808 households make self-consumption, 1966 households only sell and 187048 households consume and sell both their tubers. The types of tubers grown are: cassava occupying 230,454 farms; yam (134678farms); taro (90589 farms); sweet potato (99,264 farms); the potato (5838 farms) and; ginger (18,114 farms).

${ }^{15}$ See Mantsié and Mayéko (2018b), Directions for Agricultural Availability in Congo, Editions Universitaires Européennes. The statistics are from the general census of agriculture 2014-2017. 


\section{$\triangle$ Macrothink}

The evolution of cassava and yam yields attests the importance attached to these products. But, attests also the technique used, that of the burning, in various forms, in the whole Niari valley, in a part of Pool and Plateaux areas, has the advantage of bringing ashes to the ground, therefore a potash fertilizer (increases the soil humus content) and improve yields.

Available statistics on the evolution of cereal yields from 1993 to 2017 indicate that the average yield over the period is $6754.6 \mathrm{hg}$ per ha. The cereals occupy 185886 households for a working population of 365636 individuals. Rice production is of interest to 1225 households. The average yield of paddy rice is $6574.7 \mathrm{hg}$ per ha. The level of paddy rice yield in 2017 is far from that of 1993.

\section{The Literature on Hunger and Agricultural Productivity}

To talk about hunger is to ask questions about strategies and governance, both political and economic. Indeed, hunger begins "the agricultural force that is the primary cause of the emergence of dominant societies" ${ }^{16}$ Because the starting point of the evolution process will be in the agricultural sector, as emphasized by Ricardo $\mathrm{D}^{17}$.

To produce more, the poor farm household uses only the same amount of labor and capital (a part of previous production). But hunger can undermine farmers' productivity, as Gubbels P. (2015) has pointed out when talking about the family, a farming family in northern Ghana. "The Seidu family, faced a poor harvest, had to adopt the" one-zero-one "strategy for children and the" zero-zero-one "strategy for themselves. "One" represents a meal; "Zero" means no meal at all. Thus, during a lean season, their four children had breakfast, nothing for lunch and a meal at night. For months, Seidu and his wife had only one meal a day. The plot of land they cultivated in 2011 only allowed them to harvest three $84 \mathrm{~kg}$ bags of maize. "Two years ago that same plot produced seven bags."

It is recognized that Ghana is an example of global success in reducing hunger and poverty ${ }^{18}$, so the Seidu situation shows how a strong economic growth coexists with poverty, hunger, debt and chronic near-emergency levels of child malnutrition.

The peasant Seidu is a poor peasant who is objectively vulnerable, but he knows himself, feels vulnerable too, and this has an impact on his choices. Vulnerability thus increases vulnerability (Lallau, 2008).

Poverty is a deprivation of capabilities. Capability then is a set of functional vectors that indicate that an individual is free to lead a particular type of life (Sen, 2000). This concept of

${ }^{16}$ In the words of Rainelli P. (2007), The agriculture of tomorrow. Winners and losers of globalization. Feline Edition, Paris.

${ }^{17}$ See Wolff Jacques (1976), The Great Economic Works, Edition Cujas, 1st edition.

${ }^{18}$ Ghana has already reached the first Millennium Development Goals by halving the prevalence of hunger and is on track to halve the number of people living on less than $\$ 1.25$ a day, see Gubbels (2015). ), op. city. 
Sen's ability promotes the freedoms of each individual, and gives each society the duty to encourage them, so that a reduction of poverty and inequalities can be possible.

As the ability of a person is related to their well-being (Sen, 2000), so a poor malnourished household, deprived of capability, cannot achieve its well-being since it cannot assemble all the vectors of operations, that is to say, it cannot improve its productivity. He finds himself in a situation similar if not identical to that of the Seidu family.

The situation of the Seidu family, which is found in several African countries south of the Sahara, can thus lock up poor families, facing famine, in a sequence that, in the long run, could be very fatal. The stakes are considerable and exceed the peasants' capacity for action. They call for specific policies from policy makers.

De Castro (1952) pointed out that "few phenomena have influenced the political behavior of peoples as intensely as the food phenomenon and the tragic need to eat".

Admittedly, the management of hunger has always been a major societal and political issue. But, it seems that we are witnessing, for a decade, a (re-) politicization of the food issue (Janin and Suremain 2005), even as the fight against hunger became professional and technical (in its tools) ${ }^{19}$.

The food crisis has provided some politicians with a political scene: promising aid and help to "their populations", extolling the merits of their "food diplomacy", encouraging "produce more and eat local", denouncing the "speculative traders". Some have gained popularity gains that undoubtedly exceed the real effectiveness of the few measures taken (suspension of customs duties on imports, freezing of retail prices, food aid ...) (Janin P., 2008)

The history of the Sahel is marked by the succession of sporadic surpluses and frequent shortages. In such a halo of uncertainty and precariousness, it also seems difficult to "build oneself" as an actor of one's own life. Everyone can then be tempted to fend for themselves, weakening cohesion, trust (Akindès 2007) and household management capacity ${ }^{20}$.

The middle classes, previously unaffected by food insecurity, which is considered largely rural, have been the most affected (Janin, 2009) in poor food-deficit countries in sub-Saharan Africa.

Currently, the Sahel aid system remains designed to focus primarily on immediate needs, not on long-term risk reduction (Gubbels, 2011). For this author it is difficult to escape from the cycle of hunger. Indeed, as Paul Krugman (2000) points out, governments do not necessarily act for the national interest, especially when it comes to microeconomic interventions.

Thus, eliminating hunger requires the satisfaction of local demand for agricultural products as pointed out by Mantsié and Mayéko, (2018a) "Success in meeting local demand for food products depends on the real ends pursued by the authorities. policy makers and executives involved in the agricultural sector and the thoughtful goals they have set themselves. As

\footnotetext{
19 Janin P. (2009), op. city.

20 Janin P. (2009), op. city.
} 
suggested by Schultz, this involves their involvement in the implementation of new farming techniques, the introduction of improved seed varieties and their contribution to more efficient sources of energy, and 'in cheaper fertilizer'.

This review of the literature allows us to draw two lessons: (i) hunger is a vulnerability that increases vulnerability because it renders poor farming households unable to move, thus reducing their productivity, and (ii) improving agricultural productivity. therefore, the elimination of hunger is possible thanks to the effective and efficient involvement of the political authorities and managers involved in the agricultural sector.

\section{Econometric Analysis}

The production decisions of malnourished farm households cannot be treated like those of other economic agents. These decisions are influenced by their own characteristics as consumers. It therefore seems difficult to separate the production and consumption decisions of these underfed agricultural households.

The so-called household models interpret and analyze, other than the classical models, the behaviors of agricultural households. Based on data from a rural household survey conducted in 1994 in Ethiopia, Muller (2014) tested and confirmed the non-separation of production and consumption decisions of poor farm households.

Several authors retain models with a single equation. And when they retain two equations, each is estimated independently of the other regardless of the econometric method chosen. Also, we opt for a simple model with an equation.

In order to show the impact of hunger on the production of each individual in a malnourished farm household, the possible variables that explain this production are the number of undernourished rural poor who compose the household (IRPSA), expenditure related to agricultural production (DPA) which consists only of goods in kind (this is one tenth of the previous agricultural production) and finally land use for well-produced (OSOL).

As the cultivation of tubers concerns 236822 households or farms for an active population of 462811 individuals $^{21}$, and that the share of tuber roots in the energy supply on average over 3 years is greater than 50\% (FAO STAT 2019), we are interested here in tuber production per individual (PRTI).

Taking into account hunger or undernourishment of farm households allows us to use a linear model that looks like this:

$$
\left.\log \left(P R T I_{t}\right)=c(1)+c(2) * \log \left(I R P S A_{t}\right)+c(3) * \log \left(D P A_{t}\right)+c(4) * O S O L_{t}\right)+\varepsilon_{t}(1)
$$

We try to find c (3) and c (4) positive and c (2) negative. The normality test shows that the variables retained follow normal log and normal laws over the period 2000-2015.

\footnotetext{
${ }^{21}$ Ministry of Agriculture: General Census of Agriculture 2014-2017.
} 
Table 1. Normality test results

\begin{tabular}{|c|c|c|c|c|c|c|c|}
\hline & PRTI & LOG(PRTI) & IRPSA & LOG(IRPSA) & DPA & LOG(DPA) & OSOL \\
\hline Mean & 0.050089 & -3.019454 & 1210825. & 13.98994 & 0.051827 & -2.985470 & 2302.358 \\
\hline Median & 0.045804 & -3.083825 & 1309000. & 14.08437 & 0.047361 & -3.049955 & 2281.212 \\
\hline Maximum & 0.073151 & -2.615231 & 1421200. & 14.16701 & 0.073151 & -2.615231 & 2479.901 \\
\hline Minimum & 0.037829 & -3.274681 & 822800.0 & 13.62047 & 0.037829 & -3.274681 & 2194.261 \\
\hline Std. Dev. & 0.012218 & 0.228167 & 215442.6 & 0.195909 & 0.012433 & 0.230827 & 100.0211 \\
\hline Skewness & 0.879574 & 0.669442 & -0.833074 & -0.964975 & 0.606980 & 0.422338 & 0.423050 \\
\hline Kurtosis & 2.370112 & 2.115269 & 2.173561 & 2.387564 & 1.885551 & 1.761658 & 1.683777 \\
\hline Jarque-Bera & 2.327573 & 1.716908 & 2.306033 & 2.733188 & 1.810463 & 1.497979 & 1.632220 \\
\hline Probability & 0.312301 & 0.423817 & 0.315683 & 0.254974 & 0.404448 & 0.472844 & 0.442148 \\
\hline Sum & 0.801425 & -48.31126 & 19373200 & 223.8391 & 0.829228 & -47.76752 & 36837.72 \\
\hline Sum Sq. Dev. & 0.002239 & 0.780904 & $6.96 \mathrm{E}+11$ & 0.575707 & 0.002319 & 0.799214 & 150063.2 \\
\hline Observations & 16 & 16 & 16 & 16 & 16 & 16 & 16 \\
\hline
\end{tabular}

The probability associated with tuber root production per individual (PRTI), for example, is 0.31230 . In other words, if we reject the normality assumption of the GDPH variable, there is a $31.2 \%$ chance of making a wrong decision. The same goes for Log (PRTI), where we have a $42.8 \%$ chance.

\section{Results of the Model Estimate}

The estimation of the model by the ordinary least squares method gives the following results:

Table 2. Results of the model estimate

\begin{tabular}{crlrr}
\hline & Coefficient & Std. Error & t-Statistic & Prob. \\
\hline \hline C(1) & 6.354687 & 2.223711 & 2.857695 & 0.0144 \\
C(2) & -0.670503 & 0.131828 & -5.086201 & 0.0003 \\
C(3) & 0.273105 & 0.123660 & 2.208527 & 0.0474 \\
& 0.000357 & 0.000297 & 1.202866 & 0.2522 \\
\hline \hline R-squared & 0.987431 & Mean dependent var & -3.019454 \\
Adjusted R-squared & 0.984289 & S.D. dependent var & 0.228167 \\
S.E. of regression & 0.028599 & Akaike info criterion & -4.058568 \\
Sum squared resid & 0.009815 & Schwarz criterion & -3.865421 \\
Log likelihood & 36.46854 & Hannan-Quinn criter. & -4.048677 \\
F-statistic & 314.2532 & Durbin-Watson stat & 0.702626 \\
Prob(F-statistic) & 0.000000 & & & \\
\hline
\end{tabular}

The model estimated by ordinary least squares is as follows:

With a coefficient of determination $\mathrm{R}^{2}=0.987431$, it is found that more than $98 \%$ of the production of tuber roots by a malnourished rural poor is explained by the number of poor rural malnourished individuals, 1/10 of previous production and land occupation.

When the variables are taken individually, it is noted that at the 5\% threshold, only the IRPSA and DPA variables have a significant influence on PRTI. With R2 and the probability of F obtained, we can say that the fit of the model is of good quality.

However the good quality of the adjustment can be tainted if the model is not structurally stable. So, we did the Cusum test to detect point instabilities. The observation of the graph indicates that the curve does not cut the corridor. The model is therefore structurally stable. 


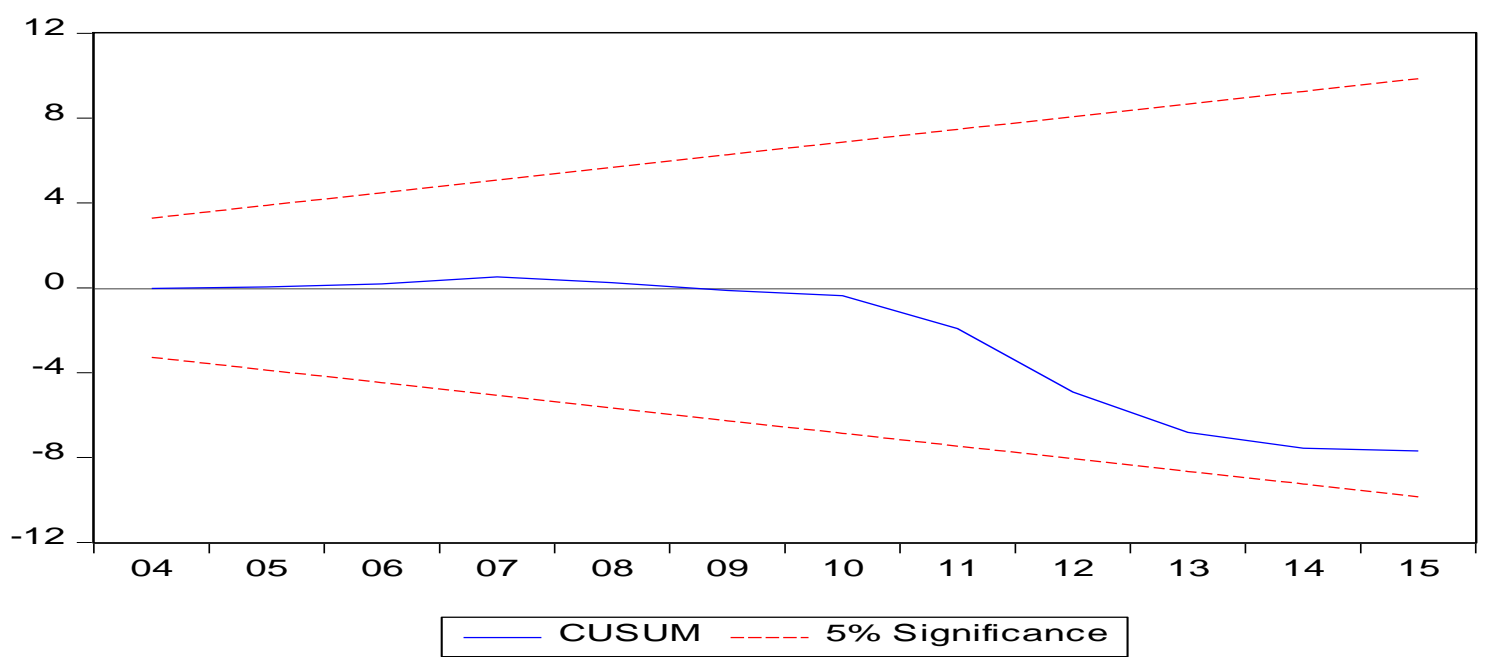

Graph 4. Structure of the model

\section{Interpreting the results}

Analysis of the results shows that with a probability of less than 5\% or a t of student (t-statistic), in absolute value, greater than 1.96, the IRPSA and DPA variables impact production. When the number of poor undernourished increases by $1 \%$, production decreases by $0.67 \%$. On the other hand, a $1 \%$ increase in the share of previous production results in an increase of $0.27 \%$.

However, these results do not allow us to show the causal relationships between the variables in order to have elements of reflections conducive to a better understanding of the impact of hunger on the productivity of tuber roots per individual. For this, cointegration makes it possible to detect the long-term relationship between two or more time series. 
Table 3. The causal relationship

Sample (adjusted): 20012015

Included observations: 15 after adjustments

Trend assumption: No deterministic trend

Series: LOG(PRTI) LOG(IRPSA)

Lags interval (in first differences): 1 to 1

\begin{tabular}{ccccc}
\hline \hline $\begin{array}{c}\text { Hypothesized } \\
\text { No. of CE(s) }\end{array}$ & Eigenvalue & $\begin{array}{c}\text { Trace } \\
\text { Statistic }\end{array}$ & $\begin{array}{c}5 \text { Percent } \\
\text { Critical Value }\end{array}$ & $\begin{array}{c}1 \text { Percent } \\
\text { Critical Value }\end{array}$ \\
\hline \hline None $*$ & 0.599581 & 14.26122 & 12.53 & 16.31 \\
At most 1 & 0.034880 & 0.532542 & 3.84 & 6.51 \\
\hline \hline
\end{tabular}

Trace test indicates 1 cointegrating equation(s) at the 5\% level

Trace test indicates no cointegration at the $1 \%$ level

$*(* *)$ denotes rejection of the hypothesis at the $5 \%(1 \%)$ level

\begin{tabular}{ccccc}
\hline \hline $\begin{array}{c}\text { Hypothesized } \\
\text { No. of CE(s) }\end{array}$ & Eigenvalue & $\begin{array}{c}\text { Max-Eigen } \\
\text { Statistic }\end{array}$ & $\begin{array}{c}\text { 5 Percent } \\
\text { Critical Value }\end{array}$ & $\begin{array}{c}\text { 1 Percent } \\
\text { Critical Value }\end{array}$ \\
\hline \hline None $*$ & 0.599581 & 13.72868 & 11.44 & 15.69 \\
At most 1 & 0.034880 & 0.532542 & 3.84 & 6.51 \\
\hline \hline
\end{tabular}

Max-eigenvalue test indicates 1 cointegrating equation(s) at the 5\% level

Max-eigenvalue test indicates no cointegration at the $1 \%$ level

$*(* *)$ denotes rejection of the hypothesis at the $5 \%(1 \%)$ level

Unrestricted Cointegrating Coefficients (normalized by $b^{\prime *} \mathrm{~S} 11^{*} \mathrm{~b}=\mathrm{I}$ ):

The observation of Table 3 indicates that $\log$ (PRTI) and $\log$ (IRPSA) variables are cointegrated at the 5\% threshold. This causal relationship confirms on the one hand, the analysis of Sen (2000) which shows a link between the ability of a person and his well-being. In fact, a malnourished person cannot achieve his well-being since he cannot gather all the vectors of operations, that is to say, he cannot improve his productivity. On the other hand, they indicate that it is difficult to escape from the cycle of hunger (Gubbels, 2011), in the extent that governments do not necessarily act in the national interest, especially when it comes to top microeconomic interventions (Krugman 2000) and therefore their involvement in the implementation of new farming techniques, the introduction of improved seed varieties and their contribution to more efficient energy sources as well as cheaper fertilizer (see Mantsié and Mayéko, 2018a).

\section{Conclusion}

Our study attempted to analyze the impact of hunger on the productivity of an undernourished individual in an agricultural household. The specification verified the impact of hunger on the production of each individual in an undernourished farm household using the possible variables that explain this production: the number of poor rural individuals undernourished, which composes the household, expenditure related to agricultural production which consists 
only of goods in kind (this is one tenth of the previous agricultural production) and finally the occupation of soils for the produced goods. Since tuber cultivation concerns 236822 households or farms for an active population of 462811 individuals and the proportion of tubers roots in energy intakes on average over 3 years exceeds 50\% (FAO STAT 2019). Here we are interested in the production of tuber roots per individual.

These results have shown that hunger affects the productivity of each individual in an agricultural household. They therefore confirm the analyses of Sen (2000), (Gubbels, 2011) of (Krugman 2000), Mantsié and Mayéko (2018a).

In face of these results, economic decision-makers must act in the national interest, as agricultural issues require sharp microeconomic interventions. And therefore involve the implementation of new breeding techniques, the introduction of improved seed varieties and the contribution of more efficient energy sources as well as cheaper fertilizers.

\section{References}

— (1995). World food situation. Rome: FAO.

— (1996a). The role of agriculture in the economy. www.fao.org/docrep. FAO

- (1996b). Congo national research system: current situation and proposal for a long-term strategy. Rome: FAO.

- (2000). Rethink inequality. Edition of the threshold.

— (2002). World Agriculture: Horizon 2015-2030, short report. Rome: FAO.

— (2008). Report on the State of food insecurity in the world. Rome: FAO.

- (2008). The staging of the fight against food insecurity in Mali: speeches, postures and games of actors. IRD, Dakar, $26 \mathrm{pp}$.

- (2018a). Supply and problem of satisfaction of local agricultural demand in Congo. Journal of agriculture and environmental sciences, 7(1), 1-12.

Akindès, F. (2007). Poverty and the construction of rights in Africa? West African review, 10.

Antonios, P. (2002). Sustainable agricultural development: dream or reality? ACP-EU mail.

Aron, J. (1995). The institutional foundations of growth, in Africa now. Paris: Karthala.

Assidon, E. (2002). Economic theories of development. Paris: the discovery 3rd Edition.

De Castro, J. (1952). Geopolitics of hunger. Paris: Editions Ouvrières.

Diata, H. (1989). Structural adjustment in Congo. Third World review January-March.

Easterly, W. (2001). Are poor countries doomed to remain so? Paris: new horizons.

Faedeau, J. C. (2015). Soil fertility indicators. Soil study and management, 22. 


\section{Macrothink}

Journal of Agricultural Studies

ISSN 2166-0379

2020, Vol. 8, No. 2

Fan, S., \& Zhang, X. (2004). Public expenditure, growth, and Poverty reduction in rural Uganda . DSGD Discussion paper 4 international food policy Research Institute Washington, D.C.

FAO/IFA. (2003). Fertilizers and their applications: accurate to the use of agricultural extension agents. 4th FAO Edition Rabat 84p.

Gubbels, P. (2011). The paths of resilience in the Sahel. Working Group on the Sahel, September.

Gubbels, P. (2015). From vulnerability to resilience in Africa. Agripade February special.

Hayami, Y., \& Vernon, W. R. (1998). Agriculture and development: an international approach. National Institute of agronomic research.

Henao, J., \& Baanante, C. Agricultural production and soil nutrient mining in Africa: implication for resource conservation and policy development. IFDC tech. Bull. International Fertilizer Development Center Muscle Shoals al. USA, n.d.

Iita. (2000). Agricultural policies for the sustainable management and use of natural resources in Africa. INTEC printers 96p.

Janin, P. (2009). The hunger riots: a (geopolitical) reading of change (social). HAL ID: IRD-00383897 http://hal.ird.fr/ird-00383897, submitted on 13 May 2009.

Janin, P., \& Charles-Édouard, de S. (2005). From Suremain. The food issue in Africa: risk and politicization. Third World review, 184, 727-859. https://doi.org/10.3917/rtm.184.0727

Jorland, G. (1995). The paradoxes of capital. Paris: Odile Jacob, 1995.

Kevin, C. (2002). Implementation of the agrigole strand: the World Bank's rural development strategy. ACP-EU mail.

Krugman, P. (2000). Globalisation is not guilty. Paris: La Découverte,.

Lallau, B. (2008). African farmers between vulnerability and resilience. For an approach by risk management capabilities. French Journal of socio-economy, 1(1), 177-198. https://doi.org/10.3917/rfse.001.0177

Mantsié, R. W., \& Mayéko, L. (2018b). Itinerary for agricultural availability in Congo. European University editions.

Mounier. (1992). Economic theories of agricultural growth. INRA-Economica co-Edition.

Mulaji, K. C. (2010). Use of household biowaste compounds to improve the fertility of acidic soils in the province of Kinshasa (Democratic Republic of the Congo. PhD thesis Université de Liège-Gembloux agro-biotech 220p.

Muller, c. (2014). A test of separability of consumption and production decisions of farm households in Ethiopia. Working papers, Aix Marseille of school of Economics (AMSE). 


\section{Macrothink}

Journal of Agricultural Studies

ISSN 2166-0379 2020, Vol. 8, No. 2

Mundlak, J., Larson, D., \& Butzer, R. (2002). Determinants of agricultural growth in Indonesia, the Philippines and Thailand. Policy research working paper World Bank Washington DC.

Nyembo, K. L. (2010). Increase in maize yield by exploiting the Heterosis effect of hybrids produced in Katanga, Democratic Republic of the Congo. PhD thesis Faculty of agronomic Sciences University of Lubumbashi 157p.

Page, J. (1994). The miracle of East Asia: laying the foundations for growth. Finance and development IMF.

Parmentier, B. (2014). Hunger zero: ending hunger in the world. Major alternative management - HEC Paris.

Plateau, J, P. (1993). Agrarian reform and structural adjustment in sub-Saharan Africa: controversies and orientations. Rome: FAO.

Rainelli, P. (2007). Tomorrow's agriculture. Winners and losers of globalisation. Edition of the Felin, Paris.

Sen, A. (1981). Poverty and famines. An essay on entitlement and deprivation, Oxford.

Wolf, J. (1976). Great economic works. Cujas 1st Edition, 1976.

World Bank. (2008). World development report. Washington: de Boeck. 


\section{Appendices}

Sample (adjusted): 20012015

Included observations: 15 after adjustments

Trend assumption: No deterministic trend

Series: LOG(PRTI) LOG(IRPSA)

Lags interval (in first differences): 1 to 1

$\begin{array}{ccccc}\text { Hypothesized } & & \text { Trace } & 5 \text { Percent } & \text { 1 Percent } \\ \text { No. of CE }(\mathrm{s}) & \text { Eigenvalue } & \text { Statistic } & \text { Critical Value } & \text { Critical Value } \\ \text { None } * & 0.599581 & 14.26122 & 12.53 & 16.31 \\ \text { At most } 1 & 0.034880 & 0.532542 & 3.84 & 6.51\end{array}$

Trace test indicates 1 cointegrating equation(s) at the $5 \%$ level

Trace test indicates no cointegration at the $1 \%$ level

$*(* *)$ denotes rejection of the hypothesis at the 5\%(1\%) level

$\begin{array}{ccccc}\text { Hypothesized } & & \text { Max-Eigen } & \text { 5 Percent } & \text { 1 Percent } \\ \text { No. of CE(s) } & \text { Eigenvalue } & \text { Statistic } & \text { Critical Value } & \text { Critical Value } \\ \text { None } * & 0.599581 & 13.72868 & 11.44 & 15.69 \\ \text { At most } 1 & 0.034880 & 0.532542 & 3.84 & 6.51\end{array}$

Max-eigenvalue test indicates 1 cointegrating equation(s) at the 5\% level

Max-eigenvalue test indicates no cointegration at the $1 \%$ level

$*(* *)$ denotes rejection of the hypothesis at the 5\%(1\%) level

Unrestricted Cointegrating Coefficients (normalized by $\mathrm{b}^{\prime} * \mathrm{~S} 11 * \mathrm{~b}=\mathrm{I}$ ):

$\begin{array}{cc}\text { LOG(PRTH) } & \text { LOG(POPRPSA) } \\ 4.667836 & 1.050824 \\ 3.998468 & 0.783469\end{array}$

Unrestricted Adjustment Coefficients (alpha):

$\begin{array}{ccc}\text { D(LOG(PRTH) }) & -0.035471 & 0.001497 \\ \begin{array}{c}\text { D(LOG(POPRP } \\ \text { SA })\end{array} & 0.033852 & 0.001765\end{array}$

1 Cointegrating Equation(s): $\quad$ Log likelihood 71.57878

Normalized cointegrating coefficients (standard error in parentheses)
LOG(PRTI) LOG(IRPSA)
$1.000000 \quad 0.225120$
(0.00448)

Adjustment coefficients (standard error in parentheses)

\begin{tabular}{ll} 
D(LOG(PRTH) $)$ & -0.165575 \\
& $(0.04053)$ \\
D(LOG(POPRP & \\
SA $))$ & 0.158015 \\
& $(0.03939)$ \\
\hline
\end{tabular}


Dependent Variable: LOG(PRTI)

Method: Least Squares (Gauss-Newton / Marquardt steps)

Date: 02/12/19 Time: 20:41

Sample (adjusted): 20002015

Included observations: 16 after adjustments

$\mathrm{LOG}(\mathrm{PRTI})=\mathrm{C}(1)+\mathrm{C}(2) * \mathrm{LOG}(\mathrm{IRPSA})+\mathrm{C}(3) * \mathrm{LOG}(\mathrm{DPA})+\mathrm{C}(4) * \mathrm{OSOL}$

\begin{tabular}{rlrr} 
Coefficient & Std. Error & t-Statistic & \multicolumn{1}{c}{ Prob. } \\
6.354687 & 2.223711 & 2.857695 & 0.0144 \\
-0.670503 & 0.131828 & -5.086201 & 0.0003 \\
0.273105 & 0.123660 & 2.208527 & 0.0474 \\
0.000357 & 0.000297 & 1.202866 & 0.2522 \\
0.987431 & Mean dependent var & -3.019454 \\
0.984289 & S.D. dependent var & 0.228167 \\
0.028599 & Akaike info criterion & -4.058568 \\
0.009815 & Schwarz criterion & -3.865421 \\
36.46854 & Hannan-Quinn criter. & -4.048677 \\
314.2532 & Durbin-Watson stat & 0.702626 \\
0.000000 & & \\
\hline
\end{tabular}

\section{Copyright Disclaimer}

Copyright for this article is retained by the author(s), with first publication rights granted to the journal.

This is an open-access article distributed under the terms and conditions of the Creative Commons Attribution license (http://creativecommons.org/licenses/by/4.0/). 